\title{
Recent Trends in Security and Stability in the South Caucasus
}

\author{
Richard Giragosian and Sergey Minasyan *
}

\section{Introduction}

After twenty years of independence, the three counties of the South Caucasus-Armenia, Azerbaijan, and Georgia - continue to struggle with a daunting set of challenges. In light of several unresolved conflicts and profound deficiencies in efforts directed at democratic and economic reform, the South Caucasus continues to be a "region at risk." As if this rather bleak landscape was not enough, three more recent trends have emerged to further threaten the region's security and stability. The first trend, and one that is likely to have the most profound effects over the long term, is evident in a subtle shift in the already delicate balance of power in the region, driven largely by a steady surge in Azerbaijani defense spending and exacerbated by a lack of progress in the mediation of the Nagorno-Karabakh conflict. Since the 1994 ceasefire that resulted in the suspension of hostilities over Nagorno-Karabakh (but that did not definitively end them), this unresolved or "frozen" conflict has been subject to an international mediation effort conducted by the Organization for Security and Cooperation in Europe's (OSCE) so-called Minsk Group. This tripartite body co-chaired by France, Russia, and the United States seeks to engage and prod the parties to the conflict toward a negotiated resolution of the conflict.

Over the past two years, however, tension has mounted significantly, clashes and attacks have escalated, and violations of the ceasefire have culminated in a renewed threat of war. In response, the primary focus of diplomatic engagement has been modified to a more "back to basics" approach, moving from outright conflict resolution to a more basic mission of conflict prevention. But the outlook for diplomacy remains rather bleak, especially as Azerbaijan sees no real progress from the peace process and has instead reverted to a policy of threatening hostilities, warning of a military option to force a resolution to the conflict. This has also led to a new danger that the NagornoKarabakh conflict may rapidly transform from a simmering (but manageable) "frozen" conflict into a new "hot" conflict. And although the warning signs of possible renewed hostilities over Nagorno-Karabakh have been clear for some time - marked by an escalation of clashes along the line of contact separating Nagorno-Karabakh from Azerbaijan - there has been far too little appreciation of the danger outside of the region.

\section{Assessing the Threat of War over Karabakh}

In terms of assessing the threat of war, recent developments suggest that the danger of renewed hostilities over Nagorno-Karabagh is now more pronounced than at any time

Richard Giragosian is the founding director of the Regional Studies Center (RSC) and Dr. Sergey Minasyan heads the Political Studies Department of the Caucasus Institute, both independent think tanks in Yerevan, Armenia. 
since the ceasefire agreement of 1994 that effectively imposed a suspension of armed conflict. More specifically, such an increasing threat of war is driven by several factors. First, Azerbaijan has sparked a dangerous "arms race" in the region, steadily increasing its defense budget over the past several years, from USD 175 million in 2004 to between USD 3.1-3.3 billion in 2011, representing nearly 20 percent of the overall 2011 state budget and including USD 1.4 billion in targeted spending for modernization "through the purchase of up-to-date equipment and weaponry."

Although Azerbaijan's steady increase in defense spending should primarily be interpreted in the light of an effort to achieve military superiority over its rivals, it also reflects a strategy to compel Armenia to match the increases in order to put pressure on the much smaller Armenian budget and to exploit the perception of Armenian economic weakness and vulnerability. Moreover, despite the serious spike in defense spending, the impact of the substantial outlays over the past several years has actually been very limited in terms of enhancing any real military capacity in Azerbaijan, mainly due to entrenched corruption within the Azerbaijani armed forces. ${ }^{2}$ More recently, however, Azerbaijan has devoted a significant proportion of its defense budget to the procurement of new, modern offensive weapon systems.

Another important factor that has only exacerbated tension is Azerbaijan's mounting frustration over the lack of progress in the Karabakh peace process. Since open hostilities were halted in 1994, the unresolved Nagorno-Karabakh conflict has been the focus of an international mediation effort aimed at forging a negotiated resolution capable of solving the inherent contradiction between the principles of self-determination and territorial integrity. What makes this current situation much more serious than earlier rounds of increased spending and rhetoric is the fact that for the first time, there is now a direct correlation between more explicit threats and greater capability for offensive military action. At the very least, the current situation necessitates a new attempt to strengthen and deepen the existing ceasefire agreement by expanding the mission and mandate for OSCE observers. Given the recent escalation of tension and sporadic clashes, addressing the vulnerability of the current ceasefire regime should be an immediate priority for the international community. Thus, there is an obvious need to ease tension, prevent war, and reinvigorate a seemingly stalled peace process. This requires a new strategy, one that is capable of ensuring that Karabakh does not move from a frozen conflict to a serious "hot" war.

1 “Azerbaijan to Nearly Double Defense Spending," Agency France-Presse (12 October 2010).

2 For more background on corruption within the Azerbaijani armed forces, see Liz Fuller and Richard Giragosian, “Azerbaijan's Unsinkable General,” Radio Free Europe/Radio Liberty (RFE/RL) Caucasus Report (14 March 2010); and Richard Giragosian, "Looking to 2020: Azerbaijan's Military Aspirations," Jane's Islamic Affairs Analyst (23 April 2008). 


\section{Nagorno-Karabakh and Deterrence Theory}

Given the improbability of reaching a final compromise solution even in the mid-term, the most important goal in the Karabakh conflict should be the preservation of stability. The context is reminiscent, at a micro-level, of the Cold War, in which stability served to prevent a war between two superpowers trapped in bipolar confrontation. This stability was made possible by the use of two complementary restraining policies - military deterrence and political containment - both of which can be fully applied to the Karabakh conflict. ${ }^{3}$ Moreover, since the threat of renewing military operations is currently coming only from Baku, a policy of deterrence is used primarily by Armenia to prevent a resumption of hostilities in Karabakh.

Basically, Armenia seeks to "increase the price of war" by threatening targets of energy production and transportation infrastructure in Azerbaijan. To do so, however, it requires weapons capable of delivering effective disruptive strikes against sensitive targets deep in hypothetical enemy territory. Taking into account the weakness of the air forces of both sides, these weapons include heavy artillery, tactical mid-range and tactical operational long-range missiles, and large-caliber multiple launch rocket systems (MLRS). When assessing the local military balance, therefore, it becomes clear that, despite its deeper arsenal of long-range missiles, Azerbaijan remains vulnerable to attacks on its energy and industrial facilities. Using its large-caliber MLRS WM- $80^{4}$ and tactical operational missile systems of the 9K72 Elbrus type (SS-1C Scud-B in NATO classification), ${ }^{5}$ Armenia has the capacity to seriously damage energy, industrial, infrastructural, and communication facilities deep within Azerbaijani territory.

Furthermore, in mid-2011, it was reported that the Armenian army possessed the new 300-mm Smerch MLRS missile system. ${ }^{6}$ Moreover, during the military parade in Yerevan on the twentieth anniversary of the independence of Armenia, four 9K79 "Tochka-U" tactical missile launchers were also publicly displayed. For a long time, Azerbaijan's own possession of such system was an argument within Azerbaijan for the resumption of hostilities. ${ }^{7}$ Baku hoped that the possession of such systems would

3 For more details see Sergey Minasyan, "The Quest for Stability in the Karabakh Conflict: Conventional Deterrence and Political Containment," PONARS Eurasia Policy Memo No. 188 (September 2011); available at www.gwu.edu/ ieresgwu/assets/docs/ponars/pepm _ 188.pdf.

4 At the end of the 1990s, Armenia acquired eight WM-80 launchers of 273-mm MLRS of Chinese make (with maximum range, depending on missile type, from 80 to $120 \mathrm{~km}$ ).

5 They were transferred to Armenia from the arms and ammunition dumps of the $176^{\text {th }}$ Rocket Brigade of the $7^{\text {th }}$ Guards Army in the course of the distribution of Soviet military property in the mid-1990s. The range of these rockets is up to $300 \mathrm{~km}$, with probable circular deviation of $0.6 \mathrm{~km}$ at large distances.

6 Sarkis Harutyunyan, “Armenian Military 'Interested' in Russian Rocket Systems,” $R F E / R L-$ Armenia (6 June 2011); available at www.azatutyun.am/content/article/24228862.html.

7 In 2004-05, Azerbaijan purchased from Ukraine twelve launchers for the 9A52 "Smerch" MLRS. The range of the "Smerch" MLRS is from 70 to $90 \mathrm{~km}$ (depending on missile type). In 2008, Baku also purchased at least four 9K79 “Tochka-U” tactical missile launchers. 
enable it to conduct "remote" military operations, thereby allowing Azerbaijani forces to avoid having to storm the Karabakh fortification line, an operation that would likely see heavy losses. But now, with its own Smerch and Tochka-U systems, and the prospects of acquiring additional long-range missile systems, Armenia's deterrent capability has been strengthened considerably. ${ }^{8}$ As a result, the Azerbaijani leadership faces a serious choice. It could instigate a full-scale military confrontation, in which both sides use heavy artillery, including MLRS and long-range missiles. However, this would lead to heavy losses and the destruction of much of Azerbaijan's energy and communication infrastructure, with no guarantee of a quick victory. Any such military conflict would also not last long, as the international community would intervene.

The alternative for Azerbaijan is to forgo using MLRS and long-range missiles in the hope that Armenia would also refrain from their use. This, however, seems unlikely. Azerbaijan would then have to restrict itself to a frontal offensive, "Stalingrad-style," over reinforced fortification lines. The heavy losses such an offensive would entail make this an unpalatable option. ${ }^{9}$ It is clearly very difficult for Azerbaijan to choose between these two operational alternatives. In either case, the price of war would simply be too high, and the possible outcomes too uncertain. Thus, it seems that Azerbaijan's leadership has for now chosen the only viable option: an arms race, hoping to exhaust Armenia and Nagorno-Karabakh. Even this arms race, however, reinforces Armenia's deterrence capacity. Armenia is able to maintain parity with Azerbaijan, despite the latter's high level of military spending, through the free and preferential arms transfers it receives from Russia, its military and political ally. The fact that Azerbaijan buys arms, even if from Russia, while Armenia receives them for free or at a heavily discounted price, gives Armenia the ability to keep up with Azerbaijan, maintaining the existing balance of power at ever higher levels of military capability, thereby reducing the likelihood of an outbreak of hostilities. This maintenance of parity is not a guarantee that military actions will not resume, but it is still a serious, and effective, deterrent.

A second important deterrent stems from the political context, with political containment rooted in the role of key international actors, which reject all consideration of a military settlement to the conflict. A related source of political containment is the possibility of direct involvement by Russia in the event of a renewal of hostilities. Currently, Armenia is the only country in the South Caucasus that has security guarantees and can expect to receive direct military assistance from a third country (Russia), as well as from a broader security alliance (the Collective Security Treaty Organization, or CSTO). The Armenian side generally operates under the presumption of a guarantee

8 It was reported in September 2011 that Armenia additionally bought eleven 220-mm 9P140 Uragan MLRS; see "Azerbaijan Deplores Reported Armenian Arms Acquisition from Moldova," RFE/RL News (17 October 2011); available at www.rferl.org/content/azerbaijan_ armenia_moldova_arms_shipment/24361791.html.

9 For a more detailed analysis of the Karabakh conflict and the issue of military balance, see Sergey Minasyan, "Nagorno-Karabakh after Two Decades of Conflict: Is Prolongation of the Status Quo Inevitable?” Caucasus Institute Research Papers \#2 (Yerevan, August 2010). 
of Russian military assistance in case of war with Azerbaijan. Formally, the obligations of Russia and the CSTO in matters of mutual defense cover only the internationally recognized borders of the Republic of Armenia, not the internal disputed borders of the territory of Nagorno-Karabakh. It is highly likely that, in the event of war, hostilities would extend beyond Karabakh and into Armenia proper. In this case, a failure to provide effective and immediate military support to a member state might discredit the CSTO, and could lead to irreparable consequences. Although Turkey and Azerbaijan have an agreement on military assistance, signed in August 2010, those provisions are vague and do not contain a commitment of direct involvement by Turkey.

\section{Provocation or Providence? Russia-Georgia Tensions}

Another recent development driving a subtle but serious shift in the regional balance of power emanates from lingering tension between Georgia and Russia. More specifically, as a result of the August 2008 "Five-day war" between Georgia and Russia, tension has actually increased as Russia has moved to consolidate and expand its military presence and support for South Ossetia and Abkhazia. Russia has bolstered its position by placing two military bases in the territories of South Ossetia and Abkhazia, which include a combined arms unit (one brigade, subdivision), engineering and artillery units, armed special forces units, as well as air defense units and a Russian Air Force presence, and the active construction and maintenance of military infrastructure (helipads in South Ossetia and a base in Ochamchira for coast guard vessels in Abkhazia). Further, in accordance with agreements with the governments of South Ossetia and Abkhazia, since January 2009 Russia has assumed responsibility for border security, which was then expanded with an agreement on 30 April 2009 allowing the deployment of Russian border troops along the perimeter of the boundaries of South Ossetia and Abkhazia with Georgia proper. ${ }^{10}$ In this context, the broader goal was the integration of the armed forces of South Ossetia and Abkhazia within a united Russian-dominated force posture.

Following the construction of these Russian military bases, the presence of a motorized infantry brigade was further bolstered by the deployment in 2010 of additional large-caliber MLRS "Smerch" weapons systems, and in December 2010, a division of the "Tochka U" tactical missile system was also deployed in South Ossetia. The de-

10 The seventh Russian military base includes a brigade deployed on a new organizational structure, as one of the first in the Russian Armed Forces that has been completed with the new T-90A tanks (forty-one tanks). Its arsenal includes more than 150 BTR-80A, two battalions of ACS 2S3 "Acacia," a battalion of MLRS BM-21 "Grad," and anti-aircraft complexes of the "Osa-AKM," ZSU-23-4 "Shilka," and 2S6M "Tunguska" types. The fourth military base in South Ossetia is largely similar to a battalion structure, but its tank battalion is armed with T-72B (M) tanks. Motorized infantry battalions are equipped with BMP-2, rather than the traditional BTR 80-As. For more, see Anton Lavrov, "The Post-war Arrangements of the Russian Armed Forces in the Newly Recognized Republics of Abkhazia and South Ossetia," in The Tanks of August, ed. R. N. Pukhov (Moscow: Centre for Analysis of Strategies and Technologies, 2010). 
ployment of such "surplus armaments" in South Ossetia (as well as in Abkhazia) far exceeds the normal limits of operational readiness for any possible renewed military action against Georgia, and can be interpreted in two ways. It could signal preparation for a possible new Russian offensive to seize the entire territory of Georgia, and even possibly extending beyond its borders. Or it could serve as a demonstration of "preventive containment" of any kind of escalation by the Georgian side along the borders of South Ossetia and Abkhazia, affirming a Russian willingness and readiness to overwhelmingly respond to even the slightest incident along the borders of the conflict zone.

Moreover, in September 2011, a member of the Presidium of the Public Council within the Russian Ministry of Defense, the well-known journalist Igor Korotchenko, warned that Russia could deploy new Mi-28N combat helicopters and the "IskanderM" tactical weapon systems in South Ossetia and Abkhazia if "Georgia continues to expand its military potential." ${ }^{11}$ Korotchenko also noted that the permanent redeployment of the new "Molnia" class missile boats as part of the Russian Black Sea Fleet to the Abkhaz port of Ochamchira was "reasonable." These developments clearly indicate that Moscow is ready to only further strengthen its military potential in South Ossetia and Abkhazia, considering it not only a platform for power projection, but also as a resource to increase its political influence throughout the region as a whole.

In turn, for the Georgian side, which no longer possesses the capacity to respond to Russian moves in Abkhazia and South Ossetia, the focus has been on leveraging negative images of Russia within global public opinion and skillfully playing on the fears, phobias, and even deep-seated anti-Russian sentiment in the West. This Georgian discourse was both directed to an internal audience and also used as an element of Georgian foreign policy. Within Georgia, the inertia of the "five-day war" served as the main narrative discourse on foreign policy and as a basis of threat perception. Although the effectiveness of the rather alarmist rhetoric of the Georgian authorities has gradually decreased, it nevertheless efficiently promoted the strengthening of the Saakashvili government through the most dangerous post-war period, until the end of 2010.

Yet overall, there is an important factor constraining Moscow from starting a new war with Georgia - namely, the direct lessons from the invasion of August 2008, and with its related threat of Russia's international isolation. Thus, it is clear that, despite the external threats and hostile rhetoric from Moscow, the danger of any new war between Russia and Georgia is quite remote. The lessening severity of this threat is also confirmed by Georgian assessments, as well as by the direction of military spending and Georgian arms procurement. Although not in the same proportion as Russia, Tbilisi has been continuing to procure armaments and military equipment in order to replace its losses from 2008, and to equip the army with new types of armaments. This, however, was not comparable to the pre-war level of defense spending, procurement,

11 "Russia Holds the Capability to Deploy Missile Systems in South Ossetia and Abkhazia," RIA News (22 September 2011); available at http://ria.ru/defense_safety/20110922/44194 2516.html. 
and acquisition. ${ }^{12}$ Moreover, according to official statistics, in 2008 (taking into account spending for the direct warfare during the August war) the Georgian military budget was about 1.625 billion laris (little more than USD 1 billion), while the military budget for 2009 was equal to 1.090 million laris (USD 665 million). In 2010, it was cut further, to 750 million laris. ${ }^{13}$

\section{The Promise of Armenian-Turkish "Normalization"}

Unlike the previous trends discussed above in terms of the shifting balance of power in the region, and the threat of renewed conflict between various regional actors, there is a third recent trend that is much more positive in nature. This trend stems from the possible restart of the Armenian-Turkish normalization, process a positive development that offers a refreshing and welcome opportunity for greater stability in the South Caucasus. Although the short-term outlook for any resumption of Armenian-Turkish diplomacy seems unlikely given the suspension of official diplomatic relations, the normalization process between the two countries does continue, although limited to smallscale civil society exchanges and "track two" efforts that merely seek to "sustain the momentum" until the two sides can return to diplomatic negotiations.

Yet over the longer term, there is more cause for optimism. The key to such renewed optimism stems not from any third country, but rather depends on strategic calculations in Ankara. More specifically, the Turkish side may actually consider returning to the stalled normalization process sooner than expected. Specifically, just as the Swiss-mediated diplomacy process between Armenia and Turkey was based on a Turkish reassessment of its strategic national interests, the scale and scope of challenges facing Turkish foreign policy today may trigger yet another reappraisal. Such a reappraisal stems from the daunting and complex long-term obstacles facing Turkey today, evident in recent developments in neighboring Syria, concerns over the Iranian nuclear program, and problems rooted in the confrontation between Turkey and Israel, to take only a few examples. In this context, the lack of any clear or immediate success in Turkish foreign policy may actually result in a policy of reengagement with Arme-

12 According to the United Nations Register on Conventional Armaments and reports from the Stockholm International Peace Research Institute (SIPRI), in 2009 Georgia imported twelve 152-mm D-20 howitzers from Bulgaria and twelve Czech 122 PC 30 RM-70 (again through Bulgaria). The shipment of thirty APC-70 DI and twenty T-72 tanks from Ukraine, which started before the August war of 2008, has been completed, as has the purchase of seventy APC Ejder from Turkey. Some data has appeared about the shipping of air defense systems from Israel. There was information about possible large procurements of new tanks and PC30 from Ukraine, although it is not clear if that shipment took place or not. In 2009, a scandal broke out in Ukraine (initiated by the opposition) about exports of AME to Georgia. See http://unhq-appspub-01.un.org/UNODA/UN_REGISTER.nsf and http://armstrade.sipri.org/ armstrade/page/trade_register.php.

13 In calculations and permanent numbers of 2008 according the methodology used by the Stockholm International Peace Research Institute (SIPRI); also see: http://milexdata.sipri.org. 
nia, with normalization offering prospects for more immediate gains, without the longterm investment and political capital required to overcome the more complex challenges facing Turkey.

Yet any such return to the normalization process will not be easy, and is not without its own unresolved challenges, inferring as it does a more sophisticated Turkish policy of sincerely engaging Armenia, facing the genocide issue more honestly and openly, and recognizing the fact that the Nagorno-Karabagh conflict can not be a direct precondition to normalizing relations with Armenia. But given the "win-win" nature of any potential Armenian-Turkish normalization, Ankara may be able to garner a key foreign policy achievement that has so far proved elusive. Nevertheless, the restart of the normalization process would now require a determination by the Turkish government to treat the Armenian issue, and all of its inherent implications, in a demonstrably more sincere manner. Only then could a second round of engagement work, especially since much of the international community sees the normalization issue quite differently than do many in Ankara, as expectations remain firmly on Turkey, with Armenia largely perceived as being more committed to normalizing relations.

It is clear that the real challenge, and the real burden, now rests with the Turkish side. It was Turkey that closed its border with Armenia in 1993 and suspended diplomatic relations. And, most crucially, it is Turkey that remains challenged by the need to face the historic legacy of the Armenian genocide. But at the same time, the normalization process between Turkey and Armenia offers a strategic opportunity and enhances regional stability by seeking to resolve disputes through diplomacy rather than force, in contrast to the deadly lessons of the Russo-Georgian war. Despite the poor record of past initiatives at normalization, however, the potential benefits from even the most basic and rudimentary form of engagement are clearly mutual for each country. For Turkey, opening its closed border with Armenia would constitute a new strategic opportunity for galvanizing economic activity in the impoverished eastern regions of the country, which could play a key role in the economic stabilization of the already restive Kurdish-populated eastern regions and thus meet a significant national security imperative of countering the root causes of Kurdish terrorism and separatism with economic opportunity. Likewise, an open border with Turkey would offer Armenia not only a way to overcome its regional isolation and marginalization, but also a bridge to larger markets that are crucial for economic growth and development.

In addition, the commercial and economic activity resulting from opening the Armenian-Turkish border would foster subsequent trade ties between the two countries that, in turn, would lead to more formal cooperation in the key areas of customs and border security. And with such a deepening of bilateral trade ties and cross-border cooperation, the establishment of diplomatic relations would undoubtedly follow. Thus, the opening of the closed Armenian-Turkish border could not only bring about a crucial breakthrough in fostering trade links and economic relations, but may also serve as an impetus to bolster broader stability and security throughout the conflict-prone South Caucasus. 
WINTER 2011

\section{Bibliography}

"Azerbaijan Deplores Reported Armenian Arms Acquisition from Moldova." RFE/RL News (2011).

"Azerbaijan to Nearly Double Defense Spending." Agency France-Presse (2010).

Giragosian, Richard. "Looking to 2020: Azerbaijan's Military Aspirations." Jane's Islamic Affairs Analyst (2010).

Harutyunyan, Sarkis. "Armenian Military 'Interested' in Russian Rocket Systems." RFE/RL-Armenia (2011).

Lavrov, Anton. "The Post-war Arrangements of the Russian Armed Forces in the Newly Recognized Republics of Abkhazia and South Ossetia." In The Tanks of August. Moscow: Centre for Analysis of Strategies and Technologies, 2010.

Minasyan, Sergey. "Nagorno-Karabakh after Two Decades of Conflict: Is Prolongation of the Status Quo Inevitable?" Caucasus Institute Research Papers 2 (2010).

Minasyan, Sergey. "The Quest for Stability in the Karabakh Conflict: Conventional Deterrence and Political Containment." PONARS Eurasia Policy Memo No. 188 (2011).

Russia Holds the Capability to Deploy Missile Systems in South Ossetia and Abkhazia In RIA News ., 2011. 